\title{
The Development Problems of Biological Beekeeping
}

\author{
Ilga Krampuža \\ Rezekne Academy of Technologies \\ Faculty of Economics and Management \\ Rezekne, Lavia \\ ilga.krampuza@rta.lv
}

\begin{abstract}
Beekeeping is an integral part of the European agricultural production. More than 620000 beekeepers work in the beekeeping branch of the European Union. Beekeeping is recognised to be an activity, which has an essential significance in the sustainable development of the rural areas, in the job-creation, the conservation of the ecosystem's biological diversity, and in the maintenance of ecological balance. The basic principle of biological beekeeping is the production of as natural produce as possible.
\end{abstract}

The study uses the analytical method to explore the current situation in the biological beekeeping sector. The analytical and comparative method helped to identify the problematic issues concerning the implementation of the beekeeping process and support measures. To study different views on the problems of biological beekeeping, the following methods for interpretation of legal norms were used: grammatical, systemic, teleological, and historical. The inductive and deductive scientific research methods were used to draw conclusions regarding current normative regulations and to recommend possible solutions. honey.

Keywords - biological beekeeping, beekeeper, bees,

\section{INTRODUCTION}

Beekeeping can be classified as follows: 1) hobby, a good way to spend time while getting additional benefit honey; 2) conventional beekeeping; 3) biological beekeeping.

The definition of the term biological beekeeping is found in connection with the interpretation of the term organic production. Organic production implies a comprehensive farm management and food production system which involves: 1) best environmental protection practices, 2) protection of biodiversity, 3) conservation of natural resources, 4) application of high animal welfare standards and production methods following the desire of a specific consumer group to use products manufactured using natural substances and processes.[2] Biological means acquired through organic production or related to it.[2] Thus, the essence of biological beekeeping involves: 1) providing people with biological beekeeping products, 2) promoting agricultural development, 3) environmental protection and conservation of natural diversity, 4) important ecosystem and agricultural services when pollinating flowers.

The development of biological beekeeping faces a range of problems, including the threats to the preservation of biological beekeeping product manufacturing, which will be reviewed further.

\section{MATERIALS AND METHODS}

The research aim is to identify and analyse the main problems of biological beekeeping development. The research methods are based on the analysis of data, documents, and normative regulations. The provisions of the European Council regulations were analysed in terms of the issues related to the necessity to create a state support system for the development of biological beekeeping, as well as the Report on prospects and challenges for the EU apiculture sector. The analytical method was used in the study to explore the current situation in the biological beekeeping sector. Using the analytical and comparative method, problematic issues were identified in the implementation of the beekeeping process as well as in the realisation of support measures.

\section{RESULTS AND DISCUSSION}

Basic regulations for biological beekeeping are determined by the general principles, which dictate the main requirements for the manufacturing methods, the use of natural resources, and limitations regarding the use 
of chemicals. From Council Regulation No. 834/2007 [2] it follows that biological beekeeping should respect: 1) Specific principles applicable to processing of organic food. These principles involve the requirement to produce honey and other beekeeping products from organic agricultural ingredients, as well as the prohibition to use non-organic ingredients, prohibition to use substances and processing methods that might mislead customers and that might imitate organic production, as well as the permission to only use organic, mechanical and physical methods for the preparation of the final product. 2) Specific principles applicable to processing of organic feed. These set the requirement to use only organic materials for the production of winter feed for bees and provide for the restriction of the use of feed additives and processing aids, so that they are used to a minimum extent and only in case of essential technological or zootechnical needs or for particular nutritional purposes.[2]

These requirements are integrated in the biological beekeeping certification process. For example, the Beekeeping Production Plan [3], which is required in the certification process, already provides for the following requirements: 1) register the beekeeping products produced by the company, 2) present the bee feed planned to be used, 3) state from the start that the bees are going to be fed with a specific product, 4) specify how much of this product is going to be used and its origin.

The requirement for detailed documentation of the biological beekeeping process, on the one hand, partly corresponds to the task set for the state under Commission Regulation No. 889/2008 to develop requirements for the production, preparation, and realisation stages of organic products. On the other hand, setting overly detailed bureaucratic requirements for accounting in addition to recording the organic production procedure involves the investment of large amounts of time and financial resources.

This is why justified criticism is heard from biological beekeepers that every year they have to fill in a total of 25 different report sheets, beginning with the hive placement plan.[4] Obviously, this requires that each of these reports is filled in and that a variety of information is accumulated, processed, and reflected. The bureaucratic procedures also include, for example, an obligatory requirement to notify the controlling authority within seven days of any changes in the numbers of hives in the apiary.

Biological beekeeping is subject to the special requirement set in Article 13 of Commission Regulation No. 889/2008 that the siting of the apiaries shall be such that, within a radius of $3 \mathrm{~km}$ from the apiary site, nectar and pollen sources consist essentially of organically produced crops and/or spontaneous vegetation and/or crops treated with low environmental impact methods. [5] Thus, apiaries must be placed in such a way that would prevent any chemicals used to treat agricultural fields from entering beekeeping products and would ensure the preservation of bee health. Following these requirements poses bigger and bigger problems.

Also, when the beekeeper brings hives to pastures, apart from submitting a report to the controlling authority (reporting the dates when specific hives are moved), there is also the requirement that pastures be organic.

The extent of intensive agriculture is growing, simultaneously reducing the area available for biological beekeeping. For example, in the period from 2000 until 2013, the crop sowing area in Latvia increased 1.39 times, reaching 584.0 thousand hectares, and rapeseed sowing area increased 17.1 times, reaching 128.2 thousand hectares.[6]

Whereas intensive agriculture, the spread of monoculture is associated with the use of chemicals throughout the entire agricultural production cycle. This includes the use of herbicides to kill unwanted plants, the use of fungicides against fungal diseases, repeated use of chemicals to promote growth, the use of insecticides against insects, the use of substances to reduce lodging, the use of chemicals intended for the ripening of the crops.

Synthetic pesticides used by industrial farmers to treat their fields not only exclude huge areas from biological beekeeping, but also kill bees. For example, in the spring of 2020, a biological beekeeper in Drabeši parish had half of the 240 colonies sheltered for winter perish. In the territory of Gauja National Park where Suda swamp reserve is located, an industrial farmer ploughed up the natural meadows next to the reserve and used synthetic pesticides for dusting rapeseed fields.[7]

Beekeepers understand that natural reduction is possible when bees die, for example, due to the spread of varroasis or from any other understandable cause. However, in the recent years, the so called "disappearing disease" has been observed when bees leave the hive and after intoxication by pesticides are unable to return to the hive. Specialists have termed this the Colony Collapse Disorder (CCD). Disappearance of bees is common in the USA, Europe, Australia and other parts of the world.

In 2019 and 2020, approximately 400 beekeepers were surveyed and spoke of the necessity to create pesticide-free areas.[7] The Regulations Regarding the Use of Plant Protection Products [8] provide for the obligation for farmers, before using plant protection products that are toxic to bees, to warn the owners of apiaries whose colonies are registered and located within a two-kilometre radius about the use of such pesticides three days in advance. However, the implementation of this condition is not going as well as it might seem because farmers look for various excuses not to inform apiary owners, for example, saying that they did not 
know about the placement of the apiary. In the survey, only $10.2 \%$ of the beekeepers responded that they had received a warning about the use of pesticides. Hence, the Regulations Regarding the Use of Plant Protection Products have justly been called a "paper law". Thus, in the future, beekeeping in Latvia in accordance with the provisions for biological beekeeping will only be possible in very limited areas.[9]

We have to agree that "in biological beekeeping, the production system needs to be created in such a way that would eliminate all pollution risks as much as possible, which is not easy at all." [10] However, in practice, if a rapeseed field is sown in the vicinity of a biological beekeeper's apiary at the distance where the bees can reach it, then, most likely, the bee colonies will have to be moved. It is in the interests of the public and specific beekeepers to reach a mutual understanding and reasonable management in order to be able to offer healthy ecological products on the market.

How seriously violations of pesticide use are treated in the world can be seen, for example, from an incident in Australia. After a fruit plantation owner sprayed pesticides over trees that were still flowering, which resulted in the death of fifty nearby colonies belonging to local beekeepers, the court in the city of Klagenfurt in Austria sentenced the fruit grower to one year in prison and ordered him to pay a 20-thousand-euro compensation for deliberately poisoning the bees. The court concluded that a professional fruit grower must have known how pesticides can harm bees and the people who were going to consume the "poisoned" honey. Whereas Denmark, to fight against excessive use of pesticides in agriculture, implemented a pesticide tax to encourage a reduction of pesticide usage.[7]

Beekeeping will always be closely related to the availability of ecological nectar plants required for bees. Of course, there are also good examples of cooperation between farmers and beekeepers, for example, in the production of rapeseed or buckwheat honey. Some seed growers also collaborate with beekeepers so that when plants are flowering, the bees deliberately placed in the fields can pollinate clover or other plants, allowing to obtain a higher yield of seeds. From the point of view of public interest, conservation of biological natural environment is very important. This would enable us to maintain the amounts of beekeeping products and to conserve the populations of bees.

It is impossible to obtain an organic bee product from materials contaminated with chemicals.

In biological beekeeping, special regulations are in place which provide for procedures for fighting bee diseases and pests. It is clear that an increase of bee mortality and decrease of bee populations in Europe can have a very negative effect on agriculture, food production, biological diversity, sustainability of the environment and the ecosystems. This is why we have to agree with the statement in the Report on prospects and challenges for the EU apiculture sector [1] that emergency measures are required at the national level to implement a broad long-term strategy to restore bee health and populations and thus conserve the population of wild bees in the EU, whose size is currently decreasing, which is why agricultural environment measures are required in order to support the creation of bee colonies. At the same time, if veterinary medication is required, a biological beekeeper must keep very detailed records of the treatment process in a special journal. The records must include the duration of the use of the medication, the active pharmaceutical ingredient, detailed information on the diagnosis, dosage, method of administration of the medication, and the duration of treatment. Whereas before selling the final product, information must be provided to controlling authorities and product testing must be performed to verify that the product is organic.

It is clear that the purpose of the special regulations for disease prevention and veterinary treatment in beekeeping is to protect frames, hives and honeycombs, especially from pests, for example, Varroa mites. Only substances suitable for biological beekeeping are allowed. For example, for apiary disinfection, physical treatment is allowed, such as using vapour or open flame. If preventive measures are ineffective, these are followed by treatment measures or even placement of specific colonies in isolated apiaries. Limited use of medication in biological beekeeping is allowed in terms of amounts as well as the restrictions allowing the use of, for example, formic acid, lactic acid, acetic acid, and oxalic acid, as well as menthol, and thymol. Usually, after the use of chemically synthesised substances, all the wax in the apiary must be replaced with organically produced wax within a specific time period. These measures require significant resources.

Additional costs in biological beekeeping result from the requirements concerning the tools and hives used. Hives must be made only from natural materials to eliminate the risk of pollution to the environment and the final product. The creation of honeycombs also requires the use of only natural materials. Moreover, only natural products may be used in hives, such as propolis, wax, and plant oils.

Obviously, the requirement in biological beekeeping to leave in the hives, at the end of the production season, enough honey and a reserve of pollen for the bees to spend the winter requires increased investments.[2] Moreover, artificial feeding of bee colonies is only allowed if their survival is threatened due to the climate and only after the last harvest of honey and 15 days before the beginning of the next nectar or honeydew collection season. Artificial feeding should be done using organic honey, organic sugar syrup, or organic sugar, [5] 
which is relatively more expensive than using ordinary sugar for preparing the feeding syrup. Moreover, an apiary journal must be completed on a regular basis, which must reflect information about the feeding of the bees, specifying when each hive was fed and the type and amount of the feed. The procedure for the supervision and control of organic farming is provided for in Cabinet Regulation No. 485. [11]

Beekeeping development prospects are also associated with the cultivation of bee species and the development of queen bee selection in the state. Admittedly, currently we need to restore the local bee species appropriate to the Latvian climate in particular, which are better able to adapt to our meteorological conditions and would be best at using the plants that are common in Latvia for collecting nectar. It is obvious that the selection process requires big financial investments. Latvia does not have any geographically isolated queen bee insemination areas - mountain regions or islands isolated from other bee colonies -, but the use of the nearest ones (for example, the islands in Estonia) is economically unprofitable because the distance disproportionately increases the transportation and tending costs. Hence, the creation of an artificial queen bee insemination system is considered more justified, which would allow queen bee breeders and selectionists to use the instrumental queen bee insemination service as close to the location of the apiary as possible. [12] Most likely, the creation of such a system would require the EU and national investments, which would undoubtedly provide a return, but of course, it can only be expected in the course of several years.

Since 1 July 2010, the use of the EU logo on organic food products has been mandatory, as has been an indication of the provenance of raw materials used in the product. This indication must be shown in the same field of vision as the EU logo.[13]

Manufacturing or the purchase of honeycombs requires significant investments. Non-organic bee wax can only be used when creating a new apiary or during a conversion period. In any other case, an opportunity and means must be found to use organic wax. Moreover, the rules for the movement of honeycombs must also be observed. Biological beekeepers must also register the removal of honey frames and extraction of honey in the apiary journal.

Biological beekeeping implies that apiary owners must comply with special controls, which are, moreover, paid for by the beekeepers. Control is performed at any production, processing, or distribution stage [14] in order to ensure the traceability of the movement of food products. Unexpected, surprise checks are practiced, which also put mental pressure on the beekeeper.

The traceability of honey and other beekeeping products starts with identification of each hive, i.e., marking each hive with a colony number; a pillow used for insulation in winter, filling in with natural materials, and the prohibition to use synthetic materials.

The beekeeping product cycle ends with the sale of the final product. Products may only be sold in specially labelled containers. Also, only special food-grade containers and special clothing must be used throughout the entire production cycle.

Realisation of the final product involves another problem - import of honey to Latvia for a disproportionately low price, which makes it difficult for local beekeepers to sell honey and other products produced in Latvia for a price that would cover all investments and allow the beekeeper to earn a living for their family. Thus, the findings in the Report on prospects and challenges for the EU apiculture sector that in 2015 more than a half of the honey imported to the EU - approximately 100000 tons or twice as much as in 2002 - was imported from China appear to be justified. Regardless of the fact that in other parts of the world the numbers of bee colonies have decreased, professionals in the beekeeping sector believe that a large part of the honey imported from China might be counterfeit and contain sugar acquired from sugarcane or corn. Not all member states are able to perform testing to discover violations regarding imported honey at the external border control points of the European Union. [1] Thus, Latvian beekeepers find themselves in the circumstances of unfair competition. Everyone can see honey-like liquids in supermarkets where the prices alone show that it cannot be real honey. Generally, the movement of biological farming products is strictly regulated in the European Union. The products offered by biological beekeepers are, of course, also subject to the general quality requirements, for example, honey packaging and storage requirements, which are not directly related to the requirements for biological farming only.[9]

Making national authorities understand the importance of the beekeeping sector and its irreplaceable contribution to the public has an important role in ensuring the protection of the interests of beekeepers. The limited understanding that our authorities have is seen even in the fact that Latvia has achieved an EU investment for state beekeeping programmes in 2021 in the amount of 207500 euro; whereas, for example, Lithuania has achieved 487114 euro respectively. [15] These numbers are a bright illustration of the situation with support for beekeeping.

Overall, such a level of support from the European Union and Latvia is required that would ensure fair competition when selling final products for an adequate price. Without political support, the bee perishing process cannot be stopped, for example, due to excessive use of pesticides, and the production of honey and other bee products will likely be impossible. 
Environment. Technology. Resources. Rezekne, Latvia Proceedings of the $13^{\text {th }}$ International Scientific and Practical Conference. Volume 1, 139-144

\section{CONCLUSIONS}

Beekeeping is an integral part of the European agricultural production. More than 620000 beekeepers work in the beekeeping branch of the European Union. Beekeeping is recognised to be an activity, which has an essential significance in the sustainable development of the rural areas, in the job-creation, the conservation of the ecosystem's biological diversity, and in the maintenance of ecological balance. The basic principle of biological beekeeping is the production of as natural produce as possible.

Biological beekeeping prescribes particular requirements:1) for the location of apiary, for example the distance until the fields where chemical treatment agents are used; 2) the usage of medicinal products for the illnesses 'combat; 3) food to feed bees additionally; 4) he turnover of the produce is also strictly regulated, therefore sale requires additional expenses

It is banned to use plant protection products and animal health products, which have a negative impact on the produce in biological beekeeping. However, it becomes more and more complicated to ensure that bees could have pastures in natural environment, as larger and larger areas are accommodated for agricultural activities, where chemicals for the flushing of plants' growing, eradication of pesticides and against lodgings are used repeatedly during the season.

The conformance to particular requirements requires additional expenses in the biological bee-keeping. It is difficult to recover the costs, selling the finished produce. Large investments are necessary for the production development of the current beekeeping produce's medical aims. Therefore, new biological beekeepers' aid schemes are necessary, involving more new participants and minimising bureaucratic procedures for receiving of the aid.

The conservation of bees' genetic heritage, which is characteristic and appropriate to Latvia's conditions is one of the beekeeping activities' challenges in order to ensure the bee-population's ability to adjust to the environmental changes and their health's hazards.

The study uses the analytical method to explore the current situation in the biological beekeeping sector. The analytical and comparative method helped to identify the problematic issues concerning the implementation of the beekeeping process and support measures. To study different views on the problems of biological beekeeping, the following methods for interpretation of legal norms were used: grammatical, systemic, teleological, and historical. The inductive and deductive scientific research methods were used to draw conclusions regarding current normative regulations and to recommend possible solutions.

\section{REFERENCES}

[1]Ziņojums par ES biškopības nozares perspektīvām un izaicinājumiem $\quad(2017 / 2115(\mathrm{INI})), \quad 2018 . \quad$ Available: https://www.europarl.europa.eu/doceo/document/A-8-20180014_LV.html\#title2[Accessed March 11, 2021]

[2] Padomes Regula (EK) NR. 834/2007(2007. gada 28. jūnijs) par bioloǵisko ražošanu un bioloǵisko produktu marḳešanu un $\begin{array}{llll}\text { par Regulas (EEK) Nr. 2092/91 atcelšanu. } & \end{array}$ Available:https://eur-

lex.europa.eu/eli/reg/2007/834/oj/?locale=LV [Accessed March 11, 2021]

[3]Ražošanas plāns biškopībā. Available: http://www.videskvalitate.lv/index.php?asad=20. [Accessed March 11, 2021]

[4]Bioloǵiskā biškopība Briǵos, Available: https://ludzaszeme.lv/biologiska-biskopiba-brigos/.[Accessed March 11, 2021]

[5] KOMISIJAS REGULA (EK) Nr. 889/2008. Available: https://eur-lex.europa.eu/eli/reg/2008/889/oj/?locale=LV. [Accessed March 11, 2021]

[6] Bioloǵiskās biškopības saimniecību pastāvēšanas iespējas LAP 2014-2020 kontekstā. Available: https://www.lbla.lv/wpcontent/uploads/2015/01/Biologiskas-biskopibas-pastavesanasiespejas-LAP_2014-2020_LBLA_22012015_Publiski.pdf.

[Accessed March 11, 2021]

[7] I.Pēttersone. Bitenieki jūtas bezspēcīgi. Kas apturēs bišu slepkavas? Available: https://www.la.lv/bitenieki-jutasbezspecigi-kas-aptures-bisu-slepkavas. [Accessed March 11, 2021] [8] Augu aizsardzības līdzekḷu lietošanas noteikumi. Ministru kabineta noteikumi No 950, 2011, Available: https:/likumi.lv/ta/id/241853-augu-aizsardzibaslidzeklu-lietosanas-noteikumi. [Accessed March 11, 2021]

[9] Medus neredzamā puse: pesticīdi-drauds biškopības nozares nākotnei. Available:https://biologiski.lv/zinas/medusneredzama-puse-pesticidi-drauds-biskopibas-nozares-nakotnei. [Accessed March 11, 2021]

[10] IEVA ŠTĀLE. Biologiskajā biškopībā dravniekam jāparedz visi riski. https://www.diena.lv/raksts/videunturisms/videsdiena/biologisk aja-biskopiba-dravniekam-japaredz-visi-riski-14173498.

[Accessed March 11, 2021]

[11] Biologiiskās lauksaimniecības uzraudzības un kontroles kārtība. Ministru kabineta noteikumi No 485, 2009. Available: https://likumi.lv/ta/id/193115-biologiskas-lauksaimniecibasuzraudzibas-un-kontroles-kartiba. [Accessed March 11, 2021]

[12] Latvijas Biškopības Programma 2020-2022. Gadam. 2019. Available:https://www.lad.gov.lv/files/ladDocument/1832/LV_ biskopibas_programma_2020-2022.pdf. [Accessed March 11, 2021]

[13] Biologiisko produktu ražošana un marḳēšana, Dokuments 32007R0834. Available:https://eurlex.europa.eu/legal-content/LV/LSU/?uri=celex:32007R0834. [Accessed March 11, 2021] 
Ilga Krampuža, et al. The Development Problems of Biological Beekeeping

[14] Pienācīgu pārtikas un dzīvnieku barības pārbaužu nodrošināšana. Available: https://eur-lex.europa.eu/legalcontent/LV/TXT/?uri=LEGISSUM:f84005. [Accessed March $11,2021]$
[15] Komisijas īstenošanas lēmums 2020.-2022.gadam. Available:https://www.zm.gov.lv/lauksaimnieciba/statiskaslapas/lopkopiba-un-ciltsdarbs/biskopibas-nozare?nid=588. [Accessed March 11, 2021] 